\title{
PENINGKATAN KETERAMPILAN MENULIS PARAgRAF DESKRIPSI MENGgUNAKAN MEDIA KARTU GAMBAR PADA SISWA KELAS IU SD NEGERI 2 GeNENG JEPARA
}

\author{
TITIK PURWANTI \\ SD Negeri 2 Geneng Kecamatan Batealit Kabupaten Jepara
}

Pertama Diterima: 24 Juli 2017

Bukti Akhir Diterima: 08 Agustus 2017

\begin{abstract}
Abstrak
Keterampilan siswa untuk menulis masih terbatas, terlebih lagi untuk dapat menulis paragraf deskripsi. Hal ini disebabkan oleh beberapa faktor, antara lain pemahaman siswa terhadap keterampilan menulis masih kurang, siswa kurang bisa membedakan antara karangan deskripsi dan narasi. Siswa tidak senang dengan pembelajaran menulis paragraf deskripsi yang monoton dan membosankan. Terbatasnya kemampuan siswa dalam menyesuaikan antara judul dengan isi karangan, penggunaan kosa kata yang belum maksimal, penggunaan ejaan dan tanda baca yang masih salah tebatasnya kemampuan siswa dalam mengembangkan gagasan atau ide menjadi suatu bentuk karangan, terbatasnya kemampuan siswa dalam berimajinasi dan memberi kesan hidup pada objek karangan. Selain itu, siswa juga belum bisa memaksimalkan penginderaan dalam menulis paragraf deskripsi. Permasalahan dalam penelitian ini ialah bagaimana meningkatkan keterampilan menulis paragraf deskripsi dengan menggunakan media kartu gambar pada siswa kelas IV SD negeri 2 Geneng Kecamatan Batealit Kabupaten Jepara dan bagaimana perubahan perilaku siswa setelah dilakukan tidakan. Penelitian ini menggunakan desain penelitian tindakan kelas (PTK). Teknik pengumpulan data menggunakan teknik tes dan nontes. Intrumen dalam penelitian ini berbentuk tes dan nontes. Instrumen tes berupa pedoman soal menulis paragraf deskripsi. Instrumen nontes berupa pedoman wawancara, pedoman pengamatan dan pedoman jurnal siswa dan guru. Pembelajaran paragraf deskripsi pada penelitian ini mengalami peningkatan. Dari pembelajaran awal siswa masih pasif dalam pembelajaran kemudian guru menggunakan media kartu gambar untuk meningkatkan pembelajaran. Siswa mengalami peningkatan pada nilai menulis paragraf deskripsi setelah menggunakan media kartu gambar.pada tahap prasiklus nilai rata-rata sebesar 65, meningkat pada siklus II menjadi 70, dan pada siklus III menjadi 76.
\end{abstract}

Kata kunci: menulis, paragraf deskripsi, media kartu gambar

\begin{abstract}
Student's skills for writing are limited, especially to be able to write a descriptive paragraph. This is caused by several factors, among others, students' understanding of writing skills is still lacking, students are less able to distinguish between the description and narration. Students are not happy with the learning of writing a descriptive paragraph that is monotonous and boring. The limited ability of students in adjusting the title with the contents of the essay, the use of vocabulary that has not been maximized, the use of spelling and punctuation is still wrong the ability of students in developing ideas or ideas into a form of essay, the limited ability of students in imagining and give the impression of life on the object essay. In addition, students also have not been able to maximize the sensing
\end{abstract}


in writing the description paragraph. The problem in this research is how to improve the skill of writing the description paragraph by using the picture card media in the fourth-grade students of state elementary school 2 Geneng Batealit Sub-district of Jepara Regency and how the student behavior change after doing the action. This study uses a classroom action research design (PTK). The technique of collecting data using test and notes technique. Instruments in this study took the form of tests and notes. The test instrument is a guide to writing a descriptive paragraph. Non-pilot instruments include interview guides, observation guides and student and teacher journal guides. Learning paragraph description in this study has increased. From the initial learning, students are still passive in learning then the teacher uses the image card media to improve learning. Students experience an increase in the value of writing the description paragraph after using the image card media. In the prusiks stage, the average value is 65, increasing in cycle II to 70, and in cycle III to 76.

Keywords: writing, description paragraph, image card media

\section{PENDAHULUAN}

Proses pembelajaran merupakan inti dari kegiatan pendidikan di sekolah. Guru memiliki tugas menjadi fasilitator, motivator, model dalam pembelajaran. Guru mampu membangkitkan semangat belajar siswa dalam proses pembelajaran karen aguru memunyaki sikap sebagai pemimpin yang bertanggung jawab. Siswa mendapatkan kematangan dalam sikapnya melalui proses pembelajaran.

Pembelajaran bahasa indonesia memeiliki ruang lingkup dalam menumbuhkan kemmapuan siswa dlaam mengungkapkan pikiran dan perasaan menggunakan bahasa yang baik dan benar. Siswa diajak berlatih dalam membaca, menulis, menyimak, dan berbicara. Pembelajaran bahasa memiliki empat aspek salah satunya menulis. Menulis merupakan salah satu cara yang digunakan seseorang untuk memberikan informasi. Keterampilan menulis dibutuhkan masyarakat baik dalam proses pembelajaran maupun dalam kehidupan seharihari. Sehingga, masyarakat diharapkan memiliki keterampilan dalam menulis.

Menulis dapat dilakukan oleh tiap orang, tetapi banyak yang belum terampil. Perlu perhatian lebih dalam hal ini. Berbeda dengan menyimak dan berbicara, menulis memerlukan latihan agar dapat terampil. Tak hanya terampil, dalam kegiatan menulis juga harus memiliki niat untuk menulis. Dimulai dengan niat, kemudian berlatih secara terus menerus sampai dia mahir dalam menulis.

Salah satu jenis menulis ialah menulis paragraf deskripsi. Deskripsi lebih menekankan pada pengungkapan melalui rangkaian kata. Identifikasi dipelukan penulis sebelum membuat paragraf deskrisi yang baik. Paragraf deskripsi merupakan karangan yang menggambarakan sesuatu yangg seolah-olah hidup atau nyata didepan mata. 
Siswa masih kesulitan dalam menulis karangan deskripsi. Hal itu disebabkan karena pemahaman siswa mengenai menulis masih kurang. Faktir lainnya ialah penguasaan kosakata siswa yang masih sedikit, keterbatasan siswa dalam mengembangkan ide pokok dalam paragraf, penggunaan ejaan dan tanda baca masih sangat terbatas.

Kendala tersebut dapat mengakibatkan pembelajaran menulis dikelas kurang efektif. Siswa butuh media yang dapat membuatnya menjadi semangat dalam belajar. Guru harus menyediakan media yang mampu membuat siswa semakin tertarik dengan menulis.

Siswa belum mampu membedakan anatara karangan deskripsi dengan karagan narasi. Kurangnya motivasi yang diberikan oleh guru ke siswa dalam hal menulis, sehingga siswa cenderung kurang semangat dalam menulis. Pemilihan sarana mengajar harus dipikirkan oleh guru karena dengan sarana yang sesuai maka, pembelajaran pun dapat tersampaikan dengan baik pula.

Salah satu sarana yang dapat digunakan guru ialah media kartu gambar. Media sendiri ialah alat yang digunakan untuk menyampaikan pesan. Kartu gambar merupakan sakah satu media yang dipakai untuk memancing seseorang dalam menjelaskan sesuatu. Media kartu gambar lebih praktis digunakan oleh guru dalam pembelajaran menulis paragraf deskripsi. Dengan sebuah kartu gambar, siswa mampu mengembangkannya menjadi satu paragraf deskripsi. Dengan cara menerjemahkan ide-ide abstrak menjadi lebih nyata.

Permasalahan dalam penelitian ini ialah bagaimana meningkatkan keterampilan menulis paragraf deskripsi dengan menggunakan media kartu gambar pada siswa kelas IV SD negeri 2 Geneng Kecamatan Batealit Kabupaten Jepara dan bagaimana perubahan perilaku siswa setelah dilakukan tidakan.

\section{METODE PENELITIAN}

Penelitian ini menggunakan desain penelitian tindakan kelas (PTK). Dalam penelitian ini digunakan prasiklus, siklus I, dan siklus II. Setiap siklus memiliki emoat tahaap, yaitu perencanaan, tindakan, observasi, dan refleksi. Sumber data dalam penelitian ini dari siswa dan guru kelas IV SD Negeri 2 Geneng. Datanya berupa skor dalam menulis karangan deskripsi dan deskripsi sikap siswa dan guru dalam pembelajaran.

Teknik pengumpulan data menggunakan teknik tes dan nontes. Teknik tes berupa soal evaluasi menulis paragraf deskripsi. Teknik nontes berupa tanggapan siswa mengenai pembelajaran menulis paragraf deskripsi. Pengumpulan melalui teknik wawancara, observasi, jurnal, dan dokumtasi foto. 
Intrumen dalam penelitian ini berbentuk tes dan nontes. Instrumen tes berupa pedoman soal menulis paragraf deskripsi. Instrumen nontes berupa pedoman wawancara, pedoman pengamatan dan pedoman jurnal siswa dan guru. Dalam teknik analisis data, peneliti menggunakan teknik kualitatif dan kuantitatif. Teknik kualitatif digunakan dalam menganalisis data nontes yang berupa kata, kalimat, dan ujaran. Teknik kuantitatif digunakan untuk menghitung data hasil tes menulis paragraf deskripsi.

\section{HASIL PENELITIAN DAN PEMBAHASAN}

Pada siklus I didapat nilai terendah 55 dan nilai tertinggi 90. Nilai rata-rata pada prasiklus adalah 65. Setelah guru melakukan tidakan pada pembelajaran dengan menggunakan media gambar, nilai rata-rata menjadi 70. Sehingga, pembelajaran mengaalami peningkatan sebesar $11 \%$. Siswa lebih siap dalam menerima penjelasan guru, lebih aktif dalam diskusi kelompok, tetapi masih kurang berani dalam menanggapi pertanyaan dan presentasi.

Tabel 1 Peningkatan Kondisi Prasiklus-Siklus I

\begin{tabular}{|c|c|c|c|}
\hline \multirow{2}{*}{ No } & \multirow{2}{*}{ Uraian } & \multicolumn{2}{|c|}{ Ulangan Harian } \\
\cline { 3 - 4 } & & Prasiklus & Siklus I \\
\hline 1 & Nilai Terendah & 55 & 55 \\
\hline 2 & Nilai Tertinggi & 85 & 90 \\
\hline 3 & Nilai Rata-Rata & 65 & 70 \\
\hline
\end{tabular}

Siklus II pada pembelajaran menulis paragraf deskripsi diperoleh nilai terendah 70 dan nilai tertinggi 90. Nilai rata-rata pada siklus I sebesr 70, setelah pembelajaran menggunkan media gambar, nilai rata-rata meningkat jadi 76. Rata-rata dari siklus I mengalami peningkatan sebesar 7,9\% pada siklus II. Siswa sudah mulai aktif saat proses pembelajaran dengan memperhatikan penjelasan guru. Siswa juga sudah aktif dalam berdiskusi, meneyelesaikan soal secara individu atau pun kelompok. Keberanian dalam bertanya/menanggapi pertanyaan dan presentasi sudah mulai mengalami peningkatan.

Tabel 2 Peningkatan Kondisi Siklus I dan siklus II

\begin{tabular}{|c|c|c|c|}
\hline \multirow{2}{*}{ No } & \multirow{2}{*}{ Uraian } & \multicolumn{2}{|c|}{ Ulangan Harian } \\
\cline { 3 - 4 } & & Siklus I & Siklus II \\
\hline 1 & Nilai Terendah & 55 & 70 \\
\hline 2 & Nilai Tertinggi & 90 & 90 \\
\hline 3 & Nilai Rata-Rata & 70 & 76 \\
\hline
\end{tabular}


Melalui penerapan media kartu bergambar dengan kelompok belajar yang dipilih oleh siswa sendiri dapat meningkatkan kemampuan memahami dan menyelesaikan soal-soal paragraf deskripsi. Dari kondisi awal ke kondisi akhir terdapat peningkatan nilai hasil ulangan harian, nilai terendah dari 55 menjadi 70, nilai tertinggi dari 85 menjadi 90 dan ratarata nilai dari 65 menjadi 76. Prosentase kenaikan dari kondisi awal ke kondisi akhir, nilai terendah naik $80 \%$, nilai tertinggi naik $10 \%$ dan rata - rata nilai naik $50 \%$.

Tabel 3 Perbandingan Peningkatan Pembelajaran

\begin{tabular}{|l|l|l|l|l|}
\hline No. & Uraian & Pra Siklus & Siklus I & Siklus II \\
\hline 1 & Nilai Terendah & 55 & 55 & 70 \\
\hline 2 & Nilai Tertinggi & 85 & 90 & 90 \\
\hline 3 & Nilai Rata-Rata & 65 & 70 & 76 \\
\hline
\end{tabular}

Kesiapan guru dalam membawa bahan ajar pada kondisi awal aktif menjadi sangat aktif. Ssiswa mendengarkan/ memperhatikan penjelasan guru kondisi awal aktif menjadi sangat aktif. Keaktifan diskusi dalam kelompok pada siswa kondisi awal sangat rendah menjadi aktif. Keaktifan siswa dalam menyelesaikan soal-saoal secara kelompok / individu kondisi awal rendah menjadi aktif, keberanian bertanya /menanggapi pertanuyaan kondisi awal sangat rendah menjadi cukup, dan keberanian mempersentasikan hasil kerja kelompok/individu kondisi sangat rendah menjadi cukup. Dari kondisi awal ke kondisi akhir proses belajar mengalami peningkatan dari rendah menjadi aktif.

\section{PENUTUP}

Pembelajaran paragraf deskripsi pada penelitian ini mengalami peningkatan. Dari pembelajaran awal siswa masih pasif dalam pembelajaran kemudian guru menggunakan media kartu gambar untuk meningkatkan pembelajaran. Siswa mengalami peningkatan pada nilai menulis paragraf deskripsi setelah menggunakan media kartu gambar.pada tahap prasiklus nilai rata-rata sebesar 65 , meningkat pada siklus II menjadi 70 , dan pada siklus III menjadi 76.

Diharapkan penelitian ini dapat meningkatkan motivasi guru dalam menggunakan media dalam pembelajaran. Dengan menggunakan media, guru lebih mudah membuat nyata beberapa materi yang terlihat abstrak bagi siswa. Bagi siswa juga dapat dengan mudah menerima pembelajaran. 


\section{DAFTAR PUSTAKA}

Arikunto, Suharsimi. (2002). Prosedur Penelitian Suatu Pendekatan Praktek Edisi Revisi V. Jakarta: Rineka Cipta.

Arikunto, Suharsimi. (2009). Penelitian Tindakan Kelas. Jakarta : Bumi Aksara.

Oemar, Hamalik. (2003). Proses Belajar Mengajar. Jakarta : Aksara. 